\title{
Family health team knowledge concerning the health needs of people with tuberculosis
}

\author{
Paula Hino ${ }^{1}$ \\ Renata Ferreira Takahashi \\ Maria Rita Bertolozzi ${ }^{3}$ \\ Tereza Cristina Scatena Villa ${ }^{4}$ \\ Emiko Yoshikawa Egry ${ }^{5}$
}

\begin{abstract}
The purposes of the study were to get to know conceptions on tuberculosis and health needs and to describe the care provided to people with tuberculosis, according to health professionals' perspective. Qualitative study developed at family health units in Capão Redondo, São Paulo. The data were collected through open interviews in January 2010 and submitted to discourse analysis, resulting in three categories: meanings attributed to tuberculosis and health needs and care characteristics. The conceptions regarding the disease are supported by the multi-causal theory of the health-disease process. The care is characterized by interventions that go beyond the biological dimension. The precarious living conditions define the needs of most people with tuberculosis, and can be more important to the ill than the very diagnosis of the disease, influencing treatment adherence, and should gain relevance in care.
\end{abstract}

Descriptors: Needs Assessment; Health Services Needs and Demand; Tuberculosis.

\footnotetext{
${ }^{1}$ RN, Post-doctoral fellow in Nursing, Escola de Enfermagem, Universidade de São Paulo, SP, Brazil. Scholarship holder of the Conselho Nacional de Desenvolvimento Científico e Tecnológico (CNPq). E-mail: paulahino@yahoo.com.br.

${ }^{2}$ RN, Ph.D. in Nursing, Associate Professor, Escola de Enfermagem, Universidade de São Paulo, SP, Brazil. E-mail: rftakaha@usp.br.

${ }^{3}$ RN, Ph.D. in Public Health, Associate Professor, Escola de Enfermagem, Universidade de São Paulo, SP, Brazil. E-mail: mrbertol@usp.br.

${ }^{4}$ RN, Ph.D. in Nursing, Full Professor, Escola de Enfermagem de Ribeirão Preto, Universidade de São Paulo, WHO Collaborating Centre for Nursing Research Development, SP, Brazil. E-mail: tite@eerp.usp.br.

${ }^{5}$ RN, Ph.D. in Public Health, Full Professor, Escola de Enfermagem, Universidade de São Paulo, SP, Brasil. E-mail: emiyegry@usp.br.
}

Corresponding Author:

Paula Hino

Universidade de São Paulo. Escola de Enfermagem

Av. Dr. Enéas de Carvalho Aguiar, 419

Bairro: Cerqueira César

CEP: 05403-000, São Paulo, SP, Brasil

E-mail: paulahino@yahoo.com.br 


\title{
Conhecimento da equipe de saúde da família acerca das necessidades de saúde das pessoas com tuberculose
}

Os objetivos do estudo foram conhecer concepções sobre tuberculose e necessidades de saúde e descrever o tipo de assistência prestada às pessoas com tuberculose, pelos profissionais de saúde. Trata-se de estudo qualitativo desenvolvido em duas unidades de saúde da família de Capão Redondo, São Paulo. Os dados foram coletados por meio de entrevista aberta, em janeiro de 2010, submetidos à técnica de análise de discurso, resultando em três categorias: significados atribuídos à tuberculose, significados atribuídos às necessidades de saúde e características da assistência. As concepções sobre a doença estão ancoradas na teoria da multicausalidade do processo saúde/doença. A assistência se caracteriza por intervenções que extrapolam a dimensão biológica. As condições precárias de vida definem as necessidades da maioria das pessoas com tuberculose, podendo ser mais importantes para os doentes do que o próprio diagnóstico da doença, influenciando a adesão ao tratamento e devendo ter maior relevância na assistência.

Descritores: Determinação de Necessidades de Cuidados de Saúde; Necessidades e Demandas de Serviços de Saúde; Tuberculose.

\section{Conocimiento del equipo de Salud de la Familia acerca de las necesidades de salud de las personas con tuberculosis}

\begin{abstract}
Los objetivos del estudio fueron conocer concepciones sobre la tuberculosis y las necesidades de salud, y describir la asistencia realizada a las personas con tuberculosis, en la perspectiva de los profesionales de la salud. Se trata de un estudio cualitativo desarrollado en dos unidades de salud de la familia en Capao Redondo, Sao Paulo; los datos fueron recolectados por medio de entrevista abierta, en enero de 2010, sometidos a la técnica de análisis de discurso, resultando en tres categorías: significados atribuidos a la tuberculosis, significados atribuidos a las necesidades de salud y características de la asistencia. Las concepciones sobre la enfermedad están basadas en la teoría de la multicausalidad del proceso salud-enfermedad. La asistencia se caracteriza por intervenciones que extrapolan la dimensión biológica. Las condiciones precarias de vida definen las necesidades de la mayoría de las personas con tuberculosis, pudiendo ser más importantes para los enfermos que el propio diagnóstico de la enfermedad, influenciando la adhesión al tratamiento y debiendo tener mayor relevancia en la asistencia.
\end{abstract}

Descriptores: Evaluación de Necesidades; Necesidades y Demandas de Servicios de Salud; Tuberculosis.

\section{Introduction}

The Family Health Strategy (FHS) has served as the framework for the implementation of collective health practices. It is the space for articulation between health services and the population and the place where health needs can be recognized(1). The latter are socially and historically determined and figure between nature and culture, that is, they do not only refer to the preservation of life, but also to the accomplishment of a life project in which the individual is progressively humanized(2). In the dialectical satisfaction of needs, it is considered that they can be technically defined without being felt and, when felt and manifested, they may turn into health service demands or $\operatorname{not}^{(3)}$. 
Difficulties to apprehend the population's health needs demand overcoming the disease-centered view as the only means to cope with users' complaints, which represent their health problems ${ }^{(4)}$. Therefore, health actions should serve to respond to users' perceived health needs, in their biopsychosocial dimensions(5). As these needs should be the object of interventions, if health professionals put in practice the needs concepts, this can improve one of their practices - active listening to health service users - considered essential to gather these needs ${ }^{(6)}$.

It is believed that treatment adherence occurs when users perceive that health professionals value and satisfy their needs. Thus, knowledge on tuberculosis (Tb) patients' health needs will allow the health team to reorient its practices, with a view to better care delivery. Tb service users share health needs with any person, besides specific needs deriving from the characteristics of this disease, among which transmissibility and the treatment type and duration stand out. In addition, Tb patients' living conditions are frequently precarious, which can influence treatment adherence and broaden their needs.

It is beyond discussion that medication treatment adherence also depends on the way the team and health service welcome the patient, that is, it is conditioned by care humanization, which involves a relationship of trust and bonding between users and professionals. Besides, the conceptions on the health-disease process people with health problems experience knowingly affect their behaviors. On the other hand, little is known about health professionals' conceptions of health needs, although it is acknowledged that their practices should be based on these needs.

In view of the above, this research aimed to get to know conceptions on the disease and health needs among Tb patients and to describe the care delivered to $\mathrm{Tb}$ patients registered at health services in the administrative district of Capão Redondo, located in Southern São Paulo City, from health professionals' perspective.

\section{Method}

An exploratory study with a qualitative approach was accomplished at two family health units, which displayed the largest number of Tb cases among health units in the administrative district of Capão Redondo. The study group comprised the health professionals responsible for care delivery to Tb patients, who received treatment at these health services at the time of data collection.

In data collection, a semistructured instrument with closed questions was used to sketch the health professionals' profile, as well as guiding questions aimed at capturing conceptions about Tb, health needs and care characteristics. The interviews were held in January 2010, in a private room at the health unit, and took an average 15 minutes. The researcher taped and fully transcribed the testimonies. Discourse analysis(7) was used to analyze the testimonies, which permitted the identification of three analytic categories: meanings attributed to $\mathrm{Tb}$, to the health needs of $\mathrm{Tb}$ patients and care characteristics. Approval for the research project was obtained from the Institutional Review Boards of the University of São Paulo at Ribeirão Preto College of Nursing and the São Paulo City Municipal Health Secretary. Those health professionals who accepted to participate in the study signed the Informed Consent Term, guaranteeing anonymity and information secrecy. With a view to guaranteeing confidentiality, the names of the family health units included in this research were not disseminated.

\section{Results}

\section{Subject description}

The interviewees comprised 16 workers, with 04 physicians, 04 nurses, 04 nursing auxiliaries and 04 community health agents (CHA). As for education, eight $(50 \%)$ held a higher education degree, while the remainder had finished secondary education. The mean age was 38 years, ranging from 26 to 59 years; only four were male; ten were married, five were single and one was widowed. The number of children varied between zero and four. When asked about complementary education, only higher education professionals indicated they had taken courses: medical residency in gynecology, pediatrics and family medicine for the physicians, and a lato sensu graduate program in collective health with emphasis on the family health program for the nurses, besides cardiology, intensive care unit, emergency care and health management. Time of work at the health units under analysis ranged from less than one to more than eight years. For half of the professionals, the time of work ranged from one to three years.

Next, the three analytic categories are described: meanings attributed to $\mathrm{Tb}$ and to $\mathrm{Tb}$ patients' health needs and care characteristics, which are presented 
in two topics, due to the first two topics' intertwined contents.

\section{Care characteristics}

Some health professionals qualified the care delivered to $\mathrm{Tb}$ patients as gratifying, when they observed improvements in their conditions, as the fruit of protocol-based treatment, which was considered as a care guide and facilitator. Also, they considered that interventions involving $\mathrm{Tb}$ patients registered at the FHS unit becomes easier than at other health services, according to one physician's testimony: the CHA already captured the patient first, then he comes through SUVIS, he practically comes with the diagnosis (Physician 3). Other professionals assessed the care as difficult, given the rebellious behavior some Tb patients adopted during the treatment period.

The activities the health professionals mentioned with regard to care delivery to Tb patients were: home visits to check the family's conditions and housing, orientation about the disease, treatment and other health-related aspects, active case search, investigation of respiratory symptomatics, communicant control, patient treatment monitoring, default prevention. Treatment encouragement was considered absolutely necessary as many patients, when symptoms improve, refuse to continue treatment or, on the opposite, if regular medication intake for a short period does not result in symptom improvement, the patient interprets that treatment is not effective, which may interfere in treatment adherence.

The following activities were mentioned as facilitators of care delivery to patients in the FHS: bonding with patients and families, which represents the team's involvement with each, knowledge shared with the client about $\mathrm{Tb}$ as a curable disease, availability of incentives to $\mathrm{Tb}$ patients during treatment, such as snacks, basic food packs and transportation aid. Regarding difficulties, the health professionals related them with non-acceptance of the disease, lack of treatment adherence, lack of family support, precarious living conditions, life habits like alcoholism and drugs abuse, constant address changes, lack of knowledge about the disease, among others.

In the present study scenario, Supervised Treatment (ST) is preferably accomplished at the health unit. Home supervision is exceptionally indicated for people with treatment adherence difficulties or who are very weakened and cannot attend the health service for this activity. In one case, in which the health team decided to conduct ST at home, the nurse assessed its accomplishment as an "inconvenience", as the need to have one professional to perform ST is not always feasible, because the team does not have sufficient professionals to deliver care to one single person, in view of other priorities at the health service. This finding is important, because it evidences the need to debate with professionals on the relevance and contribution of ST to Tb treatment.

On the other hand, health professionals indicated that ST at home permits, besides the observation of medication intake, the development of educative actions according to the person's true conditions in terms of food, housing hygiene and other health care, as it takes place "in loco" at the home and involves the family.

From the health professionals' perspective, the occurrence of $\mathrm{Tb}$ is related with precarious living conditions, poverty, agglomerations of people, bad housing conditions and with many inhabitants, unemployment, alcoholism, drug addition, bad eating habits, loss of family structure and people living on the streets, determinants which, according to them, hamper the patient's treatment adherence. They also state that the transmission of Koch's bacillus is related with the agglomeration of various people in the same room and with housing conditions, as one CHA's testimony evidences: there is a lack of hygiene, the house is dirty, very closed, no window, the floor is rustic (CHA 2).

According to the health professionals, the impact the revelation of the $\mathrm{Tb}$ diagnosis causes is sometimes revealed in people's reaction of not accepting the disease, due to the fact that they do not consider themselves ill, and also because they believe that the disease is incurable. Besides, they reported that the delay to contact the health services, the prejudice that continues regarding $\mathrm{Tb}$, hamper and delay the diagnosis of the disease, as many people feel ashamed, take time to turn to the health service and often do not reveal the diagnosis to their family and friends. Also, they affirmed that, in case of Tb-aids co-infection, acceptance of the first is more difficult, based on the behavior of one patient treated for these two illnesses.

Moreover, people's lack of knowledge about the signs and symptoms of the disease makes them not seek medical care and, when they are finally diagnosed, they already display enhanced physical weakness.

For some health professionals, many Tb patients show resistance against treatment, mainly during the first months, due to religious beliefs, and are reluctant to take the drugs, because they believe in care by their 
faith. The following report illustrates this situation, in which the neighbor of one TB patient informed the team members that the patient was deceiving them: he didn't take the drugs and used to have his mother spit in the collector to gain a negative result (Physician 3). The professionals defend that these people's psychological monitoring is fundamental for treatment adherence, associated with information about disease and treatment.

Even health professionals can deny the disease as, in one report, a professional reported that, in view of the positive result of a sputum culture, he felt reluctant to accept the disease and treatment, which demanded an intervention from the team to raise his awareness on the importance of treatment as a whole.

Also, for the professionals, the fact that Tb patients do not recognize themselves as a source of infection evidences the need to reflect with the patients on their behavior, as bacteria dissemination agents, in case they do not perform treatment correctly. Also, cases were reported in which the patient, aware of the possible bacillus transmission, feels ashamed of being an infection source.

As treatment can be extended beyond the six months the National Tuberculosis Control Program recommends, in those cases in which it is irregular or incomplete, health professionals mentioned that the participation of at least one relative in the Tb treatment process is fundamental with a view to stimulating adherence. In many situations, in view of the loss of family structure, Tb patients do not get family members' support to cope with the disease, according to the following testimony: the family went to the health service and said they did not want him at home anymore because he was coughing (Nurse 2).

\section{Meanings attributed to tuberculosis and health needs}

The health professionals considered that $\mathrm{Tb}$ patients' health needs are primarily related to the biological dimension and derive from the manifestation of signs and symptoms of the disease, such as weight loss, persistent cough, physical weakness, lack of appetite, among others. Thus, one of the first needs they identified was the confirmation of the Tb diagnosis, which comes soon after the identification of the respiratory symptomatic, whether in the community or at the health service.

The team also considered that Tb patients need dental, psychological and nutritional care, and should thus be forwarded to the Family Health Support Center (FHSC) team. The need for psychological follow-up was mentioned as essential for people with difficulties to accept the disease and treatment, with a view to treatment adherence. Hence, it was verified that necessities coexist which go beyond the disease, among which social needs stand out.

In certain poverty situations, the orientations and incentives received during treatment, such as a daily snack, bus ticket and basic food pack, are insufficient to achieve adherence, according to the professionals. The living conditions are that precarious that $\mathrm{Tb}$ constitutes but another problem to be faced, but not the main problem, as it coexists with other earlier and more intense needs than $\mathrm{Tb}$. Such situations demand integration with other community services from the health team, so as to obtain basic items for any citizen's survival, such as a mattress, bed, gas for cooking, among others. It was reported that some Tb patients' low social condition is that obvious that, if no solutions are sought for its improvement, patients are not able to take treatment forward, especially in cases of extreme poverty, associated with alcohol and drugs abuse, as the following testimony evidences: in this case, Tb treatment was the least of his problems (Physician 1).

The need for hygiene care, in terms of housing as well as personal hygiene, reflects the connection between $\mathrm{Tb}$ and low living conditions, as the following phrase shows: he needed a lot, starting with the most basic things (Nurse 3). Besides, patients' low education level is reflected in their lack of knowledge about the disease, which hampers their understanding about their condition as patients and possible bacillus transmission. Impaired self-care is present in street dwellers, and also in Tb patients who do not take care of their personal hygiene and are not interested in or do not manage to take care of their health.

The instruments used to recognize Tb patients' health needs, which the interviewees cited, were: home visit, CHA work, team meeting, medical and nursing consultation, FHSC team assistance and accomplishment of laboratory exams. The home visit was the instrument the health professionals mentioned most frequently for the identification and recognition of health needs, to the extent that it permits knowing Tb patients' family context, as an important means to detect aspects that can hamper or impede adequate treatment accomplishment.

One case a nursing auxiliary reported attracted the team's attention: during a home visit to a drug addict with irregular treatment, it was verified that the patient did not want to take the medication and spent most of the day hidden in the basement of his house, a behavior 
interpreted as a "flight" from reality. In this case, the mother's request for a home visit to her son contributed to get to know the living conditions through this activity and to identify the need to remove him from the context he was living in to be able to accomplish treatment successfully.

The professionals' search for family support and insertion in Tb treatment is more frequent in case of people living on the street. Situations were reported in which the health team looked for a patient's relative and asked him to receive him at home at least during treatment, so that the patient could look for a job after his re-establishment with a view to self-sustainment.

The professionals considered that permanent dialogue with $\mathrm{Tb}$ patients and their families, during which they orient, clarify doubts and stimulate treatment, enhances bonding, which is fundamental for treatment success. They also highlighted the importance of these people's access to knowledge on the disease, treatment and other resources available for disease control, such as communicant control, with a view to granting them responsibility for their own health and a central role in cure and in the prevention of disease transmission, contributing to their empowerment.

Coping with health needs was qualified as "troublefree" and gratifying but, in most testimonies, it was reported as "very difficulty". Difficulties start before $\mathrm{Tb}$ is diagnoses, when the respiratory symptoms have to undergo tests, but refuse to subject themselves to diagnostic tests or display difficulties to collect samples for sputum smears, despite $\mathrm{CHAs}^{\prime}$ easy delivery of recipients for domestic sample collection. The following phrase exemplifies one CHA's justification: ah, I went out yesterday, I arrived and went to bed or put the pot on top of the cupboard and didn't see it, I didn't remember (CHA 1).

The health professionals mentioned the following ways of coping with health needs: home visits to get to know the patient and family's true living conditions and environment, case discussions in the team, orientations and conversations with $\mathrm{Tb}$ patients and families, communicant control, ST at home and search for support from a relative. Coping with these needs demands meetings, not only by the health team in order to seek solutions, but also team meetings with patients and families, so as to give advice on the disease and treatment, as well as on the need to take better care of their health. Another coping form mentioned was hospitalization in Campos do Jordão, seen as an opportunity for people in precarious conditions to flee their miserable situation and receive treatment at another place. The health professionals saw this treatment mode as positive in those cases in which the team diagnoses Tb patients' difficulties to accomplish treatment if they continue in their current context, a frequent situation in case of chemical addition and extreme misery, like people living on the streets.

In case of $\mathrm{Tb}$ patients who refuse to undergo treatment, other coping strategies need to be sought, which demands mobilization and efforts from the health team, by raising the patients' awareness to adhere to treatment. Many times, without intervention and support, patient continue living in the same way, doing treatment irregularly or dropping out. Therefore, finding strategies in which social support is offered through the articulation with other services belonging to other public social entities, with people or non-governmental organizations, is defined as fundamental in this context.

\section{Discussion}

The magnitude of $\mathrm{Tb}$, associated with the treatment adherence problem and the development of multiple drug resistance, requires that health services know patients demands, so that professionals can adequately respond to their health needs. The health professionals' reports permitted identifying their conceptions and experiences in the monitoring of $\mathrm{Tb}$ patients under treatment at family health units, as well as these patients' experience, the impact of the diagnosis and their health needs.

Some health professionals mention bonding, teamwork, patient cure incentives as facilities in Tb care in the FHS context. Non-acceptance of the disease, nonadherence to treatment, lack of family support, lack of knowledge about the disease, alcoholism and drug addiction, lack of fixed housing, among others, were cited as difficulties. The importance of incorporating at least one family member to accomplish medication supervision was considered fundamental for treatment adherence. Different studies evidence experiences in which ST was accomplished by a family member instead of a health professional, reaching cure rates of more than $85 \%$, recommended by the Ministry of Health for Tb control(8-9).

They reported difficulties with regard to the families of Tb patients: how to deal with the disease not knowing, often, how to face the situation or how to offer support to the patient. Therefore, approaching the family and bonding with the health team were considered fundamental to understand the disease and treatment, as well as the importance of taking care of one's health. 
Clarifications on the disease and treatment and the importance of following the therapeutic schedule, even after symptoms improve, are factors that influence treatment adherence, given its link with people's increased awareness about their problem. Lack of knowledge about $\mathrm{Tb}$, the existence of treatment and the possibility of cure leads to a frequent problem in the control of any disease, which is treatment default(10).

As Tb treatment is only accomplished in public health services, these are privileged spaces for information dissemination about the disease and treatment and cure possibilities, and are considered a favorable environment to establish bonds and trust relations with health professionals. At the start of 2010, the research group at Universidade Federal Fluminense* conducted a public opinion survey among inhabitants from the 26 Brazilian state capitals and the Federal District, revealing that lack of information about Tb still remains one of the main challenges to control the disease. The most frequent reactions of people close to the patient after the diagnosis of the disease were mentioned as follows: separating cutlery, plates and personal objects and avoiding close contact. Only $27.2 \%$ of all interviewees said that nothing had changed in interactions at home when the TB diagnosis was confirmed. Besides, most interviewees believed hospitalization was necessary for Tb treatment.

When they found out about their Tb diagnosis, most people reacted with fear, refusal and insecurity, and many believe that $\mathrm{Tb}$ is an incurable disease ${ }^{(10)}$. Thus, health professionals should be sensitive to the fact that patients may demand psychological support to cope with the disease and treatment ${ }^{(11)}$. Hence, care delivery to Tb patients goes beyond medication intake, demanding professional preparation to deal with patients' countless needs and demands ${ }^{(12)}$.

Studies on the aspects involved in the revelation of the HIV diagnosis in children and adolescents reveal that, despite the initial impact, knowing the diagnosis positively influenced health care and improved the dialogue between parents or caregivers and the health team. The need to actively support adolescents is highlighted though after their health conditions has been revealed, with a view to possible conflicts and difficulties that may emerge, as well as to reduce the stigma that surrounds the disease(13).

According to health professionals, Tb patients' health needs are related with signs and symptoms of the disease, diagnosis and treatment, and associated with social conditions and other situations that do not derive from the diagnosis, like the need for dental, psychological and nutritional care, among others. The precarious living conditions affecting most Tb patients can significantly interfere in treatment adherence and represent one of the main reasons for treatment default.

It is fundamental for the health team to consider the reasons that make people adhere to or abandon Tb treatment. Treatment adherence derives from the bond established between health professionals and Tb patients, from care humanization, and also from the valuation of the needs these people feel. The health team's construction of a more operational health needs concept is considered a device to qualify and humanize health services ${ }^{(14)}$. Therefore, to acknowledge health needs, health needs identification instruments can facilitate and support decision making, as they permit the systematic survey of true health-related needs, besides contributing to their coping in FHS practice(15).

\section{Final considerations}

The analysis of testimonies permitted identifying conceptions on $\mathrm{Tb}$, health needs and characteristics of $\mathrm{Tb}$ patient care, from the perspective of health professionals, with these people's health needs as the guiding axis. It is highlighted that treatment success involves issues that go beyond regular medication intake, such as food, housing conditions, employment, information and health service access, as well as the establishment of bonding with the health team.

Care quality in Tb control demands that health professionals develop a care practice characterized by the absence of prejudice, acceptance of $\mathrm{Tb}$ patients and willingness to act, understanding the social problem that is present in the occurrence and manifestation of this disease in certain people. The study evidenced that it is fundamental to share professional experiences, whose actors, in daily reality, monitor clients with a view to the adoption of healthy practices, besides demonstrating health professionals' possibilities when choosing to deliver care to Tb patients, focusing on health needs. This practice demands the construction of a new work process among team professionals and Tb patients, with a view to the establishment of active mutual listening, co-accountability between team and users

\footnotetext{
* Research performed by DATA UFF and the Fundo Global Tuberculose Brasil project.
} 
and a relationship of dialogue to capture Tb patients' true needs. The researchers hope this study will arouse reflections among health professional who deal with Tb patients and will broaden discussions about health needs, contributing not only to teaching-research, but mainly to a better care delivery.

\section{References}

1. Egry EY. Apresentação. In: Egry EY. Necessidades de saúde na perspectiva da atenção básica: Guia para pesquisadores. São Paulo (SP): Dedone; 2008. p. 9-10. 2. Melo DA Filho. Repensando os desafios de Ulisses e Fausto: a saúde, o indivíduo e a história. Cad Saúde Pública. 1995;11(1):5-20.

3. Stotz EM. Os desafios para o SUS e a Educação Popular: uma análise baseada na dialética da satisfação das necessidades de saúde. In: Ministério da Saúde 9BR). Secretaria de Gestão e Trabalho e da Educação na Saúde. Rev-SUS Brasil. Cadernos de textos. Brasília; 2004.

4. Egry EY, Oliveira MAC. Marcos teóricos e conceituais de necessidades. In: Egry EY. Necessidades de saúde na perspectiva da atenção básica: Guia para pesquisadores. São Paulo(SP): Dedone; 2008. p. 33-40.

5. Silva AG Júnior, Merhy EE, Carvalho LC. Refletindo sobre o ato de cuidar de saúde. In: Pinheiro R, Mattos RA. Construção da integralidade: cotidiano, saberes e práticas em saúde. Rio de Janeiro (RJ): IMS-UERJ; 2003. p. 89-112.

6. Cecílio LCO. As necessidades de saúde como conceito estruturante na luta pela integralidade e eqüidade na atenção em saúde. In: Pinheiro R, Mattos RA. Os sentidos da integralidade na atenção e no cuidado à saúde. Rio de Janeiro: UERJ; 2001. p. 113-26.

7. Fiorin JL, Savioli FP. Para entender o texto: leitura e redação. São Paulo (SP): Ática; 1991.

8. Maciel ELN, Silva AP, Meireles W, Fiorotti K, Hadad DJ, Dietze R. Tratamento supervisionado em pacientes portadores de tuberculose utilizando supervisores domiciliares em Vitória, Brasil. J Bras Pneumol. jul 2008;34(7):506-13.

9. Maciel ELN, Guidoni LM, Brioshi AP, Prado TN, Fregona G, Hadad DJ, et al. Household members and health care workers as supervisors of tuberculosis treatment. Rev Saúde Pública. abr 2010;44(2):339-43.
10. Hasker E, Khodjikhanov M, Sayfiddinova S, Rasulova G, Yuldashova U, Uzakova G, et al. Why do tuberculosis patients default in Tashkent City, Uzbekistan? A qualitative study. Int J Tuberc Lung Dis. 2010;14(9):1132-9.

11. Paz EPA, Sá AMM. The daily routine of patients in tuberculosis treatment in basic health care units: a phenomenological approach. Rev. Latino-Am. Enfermagem. 2009 Mar-Apr;17(2):180-6. Inglês, Português, Espanhol.

12. Queiroz EM, Bertolozzi MR. Tuberculose: tratamento supervisionado nas Coordenadorias de Saúde Norte , Oeste e Leste do Município de São Paulo. Rev Esc Enferm USP. jun 2010;44(2):453-61.

13. Marques HHS, Silva NG, Gutierrez PL, Lacerda $\mathrm{R}$, Ayres JRCM, Dellanegra $M$, et al. A revelação do diagnóstico na perspectiva dos adolescentes vivendo com HIV/AIDS e seus pais e cuidadores. Cad Saúde Pública. mar 2006;22(3):619-29.

14. Cecílio LCO, Lima MHJ. Necessidades de saúde das pessoas como eixo: a integração e a humanização do atendimento na rede básica. In: Linhares AL. Saúde e Humanização: a experiência de Chapecó. São Paulo(SP): Hucitec; 2000. p. 159-82.

15. Hino $\mathrm{P}$, Ciosak SI, Fonseca RMGS, Egry EY. Necessidades em saúde e atenção básica: validação de instrumentos de captação. Rev Esc Eferm USP. 2009;.43(no.spe 2):1156-67. 